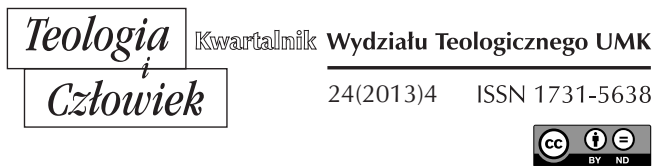

IRENEUSZ KAMIŃSKI*

TORUŃ

\title{
V TORUŃSKIE SYMPOZJUM POŚWIĘCONE ALTERNATYWNYM RUCHOM RELIGIJNYM PT. „DUCHOWOŚĆ DALEKIEGO WSCHODU A CHRZEŚCIJAŃSTWO. DIALOG CZY KONFRONTACJA?" TORUŃ, 12-14 LISTOPADA 2013 ROKU \\ DOI: http://dx.doi.org/10.12775/TiCz.2013.054
}

W Toruniu w auli Centrum Dialogu Jana Pawła II (pl. S. Frelichowskiego 1) w dniach 12-14 listopada 2013 r. - niejako na zakończenie Roku Wiary - odbyło się kolejne już $V$ Toruńskie Sympozjum poświęcone Alternatywnym Ruchom Religijnym. Jego tematyka koncentrowała się na ruchach religijnych i parareligijnych, które wywodzą się z religii i duchowości Dalekiego Wschodu, a które są obecne w naszym kręgu kulturowym i cywilizacyjnym. Sympozjum nosiło tytuł „Duchowość Dalekiego Wschodu a chrześcijaństwo. Dialog czy konfrontacja?" Głównymi organizatorami tego wydarzenia byli: Wydział Teologiczny UMK w Toruniu i Urząd Marszałkowski Województwa Kujawsko-Pomorskiego w Toruniu. Do pozostałych współorganizatorów należały również: Stowarzyszenie Kultury Chrześcijańskiej im. ks. Piotra Skargi i Instytut ks. Piotra Skargi

* Ireneusz Kamiński, magister prawa, absolwent UMK w Toruniu. Związany z Pracownią Dokumentacji i Badań Alternatywnych Ruchów Religijnych i Parareligijnych Uniwersytetu Mikołaja Kopernika w Toruniu. 
oraz PCh24.pl; Katolickie Stowarzyszenie "Civitas Christiana" Oddział Okręgowy w Toruniu; Wydział Zdrowia i Polityki Społecznej Urzędu Miasta Torunia; Centrum Badań nad Mniejszościami Religijnymi w Toruniu, Samorząd Studencki Wydziału Teologicznego UMK.

Podczas obrad sympozjalnych referenci zastanawiali się, na ile idee pochodzące z hinduizmu, dżinizmu, sikhizmu, buddyzmu, konfucjanizmu, taoizmu, szintoizmu itd. zaznaczają swą obecność w cywilizacji zachodniej (chrześcijańskiej). Rozważania dotyczyły nie tyle „mgławicowych" koncepcji nurtu New Age, ile raczej chodziło o krytyczne spojrzenie na kwestie związane $\mathrm{z}$ praktykami i wpływami azjatyckich duchowości na ludzi Zachodu, na ich poglądy antropologiczne, mentalność oraz postrzeganie świata duchowego i religijnego. W sposób naukowy przyglądano się różnicy między medytacjami, terapiami, modlitwami i tzw. życiem religijnym, które proponują emisariusze z Dalekiego Wschodu a - częstokroć zapomnianym - bogactwem medytacji i modlitwy chrześcijańskiej. Ukazywano m.in. problem przystawalności antropologii/ teologii i metod modlitwy Wschodu do uniwersum tradycji chrześcijańskiej oraz zagrożeń, jakie niesie ze sobą - związane $\mathrm{z}$ indyferentyzmem wielu Europejczyków - pomieszanie pojęć w tej materii.

Naukowe poszukiwania zainspirowane zostały m.in. wytycznymi i wskazaniami zawartymi w tzw. Raporcie Watykańskim z 1986 r. (Sekty albo nowe ruchy religijne. Wyzwanie duszpasterskie Raport watykański, Watykański Sekretariat Jedności Chrześcijan, Sekretariat dla Niechrześcijan, Sekretariat dla Niewierzących, Papieska Rada do spraw Kultury, Rzym, 1986 r.) $)^{1}$. Dokument ten w 6 rozdziale (Zagadnienia do dalszych studiów i badań) wymienia obszary, na których winny koncentrować się badania, jakie można prowadzić w odniesieniu do alternatywnych ruchów religijnych i parareligijnych (dalej: arr) i innych tego typu zjawisk wywodzących się z religii Dalekiego Wschodu. Należą do nich:

1. Studia o charakterze teologicznym,

2. Studia interdyscyplinarne,

3. Studia psychologiczne i pastoralne,

4. Sekty a rodzina,

5. Kobiety w sektach,

${ }^{1}$ Inna nazwa dokumentu: Zjawisko sekt $i$ nowych ruchów religijnych. Wyzwanie duszpasterskie 1985; Il fenomento delle sete o nuovi movimenti religiosi. Rapporto provvisorio, Roma 1958, cap. 3; (Enchiridion Vaticanum, X vol., EDB Bologna 1989, 402-414). Zwany jest także: Dokumentem Watykańskim na temat Sekt. 
6. Adaptacja kulturowa i inkulturacja sekt oraz ich ewolucja w różnych kontekstach kulturowych i religijnych,

7. Studium ruchów młodzieżowych,

8. Wolność religijna w odniesieniu do sekt - aspekty etyczne, prawne i teologiczne,

9. Obraz sekt w opinii publicznej i wpływ opinii publicznej na sekty ${ }^{2}$.

Referaty sympozjalne poprzedzał wykład Roberta Tekieli redaktora i publicysty niezależnego, pt. Zagrożenia duchowe pochodzace ze Wschodu we wspótczesnej kulturze Zachodniej (m.in. reinkarnacja, joga, sztuki walki, medytacja), który został wygłoszony wieczorem pierwszego dnia sympozjum. Po wykładzie odbyła się dyskusja.

Sympozjum oficjalnie otworzył $\mathrm{w}$ dniu następnym (13 listopada) Dziekan Wydziału Teologicznego UMK - ks. prof. dr hab. Dariusz Kotecki, który przywitał referentów i innych uczestników tego naukowego spotkania oraz dokonał krótkiego wprowadzenia w jego problematykę. Głos zabrali także: ks. prof. dr hab. Jan Perszon - kierownik naukowy sympozjum i Piotr Hoffmman - Przewodniczący Oddziału Okręgowego Katolickiego Stowarzyszenia „Civitas Christiana” w Toruniu.

Pierwszej sesji przewodniczył ks. dr hab. Piotr Roszak z Zakładu Teologii Fundamentalnej i Religiologii Wydziału Teologicznego UMK. Referaty tu przedstawili: prof. dr hab. Viara Maldjieva z Instytutu Filologii Słowiańskiej UMK (Jezykowe świadectwa wpływów azjatyckiej duchowości na wspótczesnego Europejczyka); ks. prof. dr hab. Jan Perszon z Zakładu Teologii Fundamentalnej i Religiologii Wydziału Teologicznego (dalej: WT) UMK (Różaniec - kontynuacja Modlitwy Jezusowej Wschodu); ks. prof. dr hab. Jarosław Popławski z Katedry Historii Duchowości Instytutu Teologii Duchowości WT KUL (Znaczenie $i$ rola medytacji w poznaniu $i$ formacji duchowej człowieka); O. prof. dr hab. Adam Sobczyk MSF z Zakładu Teologii Duchowości WT UMK (Medytacja chrześcijańska wedtug Hansa Ursa von Balthasara. Specyfika, metoda, różnice i możliwości integracji z medytacja niechrześcijańska); ks. prof. dr hab. Marek Chmielewski z Katedry Teologii Duchowości Katolickiej Instytutu Teologii Duchowości WT KUL (Doświadczenie duchowe podstawa medytacji chrześcijańskiej); ks. dr Andrzej Wańka z Katedry Teologii Fundamentalnej WT Uniwersytetu Szczecińskiego (Wschodnie inspiracje zachodniego ezoteryzmu) oraz dr Krzysztof Pilarz

${ }^{2}$ Dokument stwierdza, iż „O ile to możliwe, takie studia i badania powinny być podejmowane przy współpracy ekumenicznej”. 
z Zakładu Pedagogiki Pastoralnej WT UMK (Synkretyzm antropologiczny a wychowanie chrześcijańskie).

Drugą sesję prowadził dr Piotr Chrzczonowicz z Wydziału Prawa i Administracji UMK. Referaty zaprezentowali: mgr Łukasz Kamiński z Instytutu Filozofii Uniwersytetu Warmińsko-Mazurskiego w Olsztynie (Problem relatywizmu etycznego $i$ wyjścia poza dobro $i$ zło w filozofii buddyzmu zen); Stanisław Chłościński prezes Stowarzyszenia „Wyzwoleni” z Poznania (Religie Wschodu - zakazany owoc, czy na pewno? Stosunek Towarzystwa Strażnica a postawa jej członków wobec: buddyzmu, hinduizmu i jogi - na podstawie materiałów źródłowych: czasopism $i$ wydawnictw tej organizacji); ks. prof. dr hab. Andrzej Zwoliński z Wydziału Nauk Społecznych Uniwersytetu Papieskiego JP2 w Krakowie (Reinkarnacja, jako alternatywne wirtualne życie); mgr Anna Łobaczewska przewodnicząca Ruchu Obrony Rodziny i Jednostki (dalej: RORiJ) („Przywrócić życiu”. Świadectwo uwikłania w Misję Czajtanii - Instytut Wiedzy o Tożsamości); ks. dr Bolesław Karcz z Wydziału Nauk Społecznych Uniwersytetu Papieskiego JPII $\mathrm{w}$ Krakowie (Wptyw idei reinkarnacji na koncepcje wychowania w rodzinie) oraz ks. dr Stanisław Radoń także z Wydziału Nauk Społecznych, UP JPII (Uważność medytacyjna - naukowe wyzwanie do dialogu religijnego).

Przewodnictwo nad trzecią sesją objął ks. prof. dr hab. Jan Perszon. Uczestnicy sympozjum mieli okazję usłyszeć wystąpienia: dr hab. Iwony Massaki z Katedry Hermeneutyki Polityki Wydziału Politologii i Studiów Międzynarodowych (dalej: WPiSM) UMK (Anarchistyczno-heterodoksyjny wymiar tołstoizmu); dr. Dariusza Hryciuka z Centrum Przeciwdziałania Psychomanipulacji w Lublinie (Charakterystyka i zasieg oddziatywania grupy kultycznej o charakterze hinduistycznym "Misja Czajtanii"); Siostry B.A. Michaeli Pawlik OP z RORiJ (Wptyw Wschodu na duchowość Zachodu); ponownie dr. D. Hryciuka (Dalekowschodnie wątki w produkcjach filmowych $i$ ich wptyw na postawy i przekonania młodzieży); Macieja Angutka, (Syndrom tężyczki wywotywanej hiperwentylacja w medytacyjnych praktykach oddechowych - referatu przygotowanego wspólnie z dr Dorotą Angutek z Instytutu Socjologii Uniwersytetu Zielonogórskiego); dr Agnieszki Lisieckiej-Bednarczyk z Wyższej Szkoły Zarządzania „Edukacja” we Wrocławiu (Ideat edukacyjny w "Edukacji Idealnej”. Program wprowadzania Medytacji Transcendentalnej (TM) w polskich szkołach) i Patryka Gacki reprezentującego Zespół Prawa Międzynarodowego „Ius Gentium” na Wydziale Prawa i Administracji UW (Status prawny sekt w PRL-u i III RP. Omówienie metoda porównawcza), a także po raz drugi Siostry B.A. Michaeli Pawlik OP (Polityczne podłoże ekspansji hinduizmu na cywilizacje Zachodu). 
Referaty do odczytu przesłali ks. prof. Ján Šafin z Katedry Historii Kościoła i Bizantynologii Wydziału Teologii Prawosławnej Preszowskiego Uniwersytetu w Preszowie na Słowacji (Vnímanie času v krestanskej a orientalnej filozofii a historiozofia - Postrzeganie czasu w filozofii chrześcijańskiej i orientalnej oraz w historiozofii) oraz bp prof. dr hab. Andrzej Siemieniewski z Instytutu Teologii Duchowości Papieskiego Wydziału Teologicznego we Wrocławiu (Jak medytować po chrześcijańsku?). Po tej sesji przewidziano dyskusję.

W kolejnym dniu obrad (14 listopada) animatorem sympozjum był także ks. prof. dr hab. Jan Perszon. Przedstawiono tego dnia następujące referaty: prof. dr hab. Robert T. Ptaszek z Katedry Teorii Religii i Alternatywnych Ruchów Religijnych KUL (O mylacych schematach $i$ groźnych nieporozumieniach będacych rezultatem odwotywania się przez przedstawicieli zachodniej kultury do tak zwanej „Duchowości Wschodu”); ks. prof. dr hab. Leonard Fic z Instytutu Dialogu Kultury i Religii UKSW (Medytacja Wschodu, jako wyzwanie dla chrześcijaństwa); O. prof. dr hab. M. Celestyn Paczkowski OFM z Zakładu Patrologii i Antyku Chrześcijańskiego WT UMK (Czym jest duchowość chrześcijańskiego Wschodu?); prof. dr hab. Paweł Sajdek z Katedry Historii Filozofii Starożytnej i Średniowiecznej KUL (Spotkanie z cywilizacja Indii - zagrożenie czy szansa?); po raz trzeci S. B.A. M. Pawlik OP (Akomodacja religii Wschodu na Zachodzie); Joanna Zabłudowska z Dominikańskiego Centrum Informacji o NRR i Sektach w Gdańsku (Iluzje fatszywych mędrców w filmie "Dawid chce odlecieć" (reż. David Sieveking) jako pomoc medialna w rozeznaniu destrukcyjnej duchowości Wschodu); mgr lic. Arkadiusz Król z Instytutu Ekumenicznego KUL (Religie Dalekiego Wschodu w dialogu ze wspótczesnym chrześcijaństwem $w$ świetle nauczania Kościoła katolickiego); mgr Alicja Stańco z Katedry Dziennikarstwa i Komunikacji Społecznej WPiSM UMK (Aum Shinriky (Aleph) - wschodnia myśl realizowana zachodnia przemoca); mgr Milena Marciniak z Instytutu Filozofii UMK (Wzajemne przenikanie się wątków buddyjskich i chrześcijańskich w filozofii człowieka Artura Schopenhauera); mgr Anna Gładkowska z UP JPII w Krakowie (Przeszkody na drodze dialogu międzyreligijnego i zasady jego owocnej realizacji w nauczaniu Benedykta XVI „,apostota dialogu i pokoju”); mgr Natalia Stala z Katedry Religioznawstwa i Filozofii Wschodu Wydziału Filozofii i Socjologii Uniwersytetu Marii Curie-Skłodowskiej (Czy joga jest terapiq?); mgr Maciej K. Grzywacz z WPiSM UMK (International relations and religion. Seeking for sacredprofane equilibrium); po raz drugi mgr lic. Arkadiusz Król (Działalność „Misji Czajtanii" na przykładzie województwa lubelskiego) oraz mgr Michał 
Płóciennik, UP JPII w Krakowie (Z-chrystianizowany zen czy z-zenizowane chrześcijaństwo? Analiza krytyczna propozycji benedyktyna i mistrza zen Willigisa Jägera), a także mgr Agata Kłocińska z Zakładu Filozofii Religii Instytutu Filozofii Uniwersytetu Warszawskiego (Cud a zjawiska niezwykte. Istotne różnice pomiędzy koncepcja buddyjskq a chrześcijańska).

Trzy zaplanowane na tę sesję wystąpienia nie odbyły się z powodu absencji referentów: bp prof. dr. hab. Andrzeja Siemieniewskiego (Wspótczesna medytacja monologiczna); dr Moniki Wojtkowiak z Zakładu Profilaktyki Społecznej i Resocjalizacji Uniwersytetu Jana Kochanowskiego $\mathrm{w}$ Kielcach (Poradnictwo w zakresie sekt $i$ nrr o proweniencji wschodniej - działania pomocowe $i$ naprawcze - postulaty, oczekiwania, możlizwości $i$ ograniczenia) oraz red. dr. Borisa Rakovskýego, redaktora naczelnego czasopisma "Rozmer" ze Słowacji (Spiritualita hinduismu a jego wplyw na zachodnju cywilizacju - Duchowość hinduizmu i jej wpływ na zachodnią cywilizację). Teksty ich wystąpień zostały przesłane organizatorom celem udostępnienia uczestnikom sympozjum.

Zaprezentowane podczas sympozjum referaty miały wysokie walory poznawcze, inspirowały do dyskusji i rozmów kuluarowych. Warto wspomnieć, że planowane jest opublikowanie wygłoszonych referatów w postaci książkowej. 